WBS: 1.2 .2

QA: QA

Civilian Radioactive Waste Management System

MOL. 19991004.0399 Management \& Operating Contractor

\title{
Waste Package Operations FY-99 Closure Methods Report
}

TDR-EBS-ND-000002 REV 00

\section{September 1999}

Prepared for:

U.S. Department of Energy

Yucca Mountain Site Characterization

Project Office

P.O. Box 30307

Las Vegas, Nevada 89036-0307

\section{Prepared by:}

TRW Environmental Safety Systems Inc. 1261 Town Center Drive

Las Vegas, Nevada 89144

Under Contract Number

DE-AC08-91RW00134 


\section{DISCLAIMER}

This report was prepared as an account of work sponsored by an agency of the United States Government. Neither the United States Government nor any agency thereof, nor any of their employees, nor any of their contractors, subcontractors or their employees, makes any warranty, express or implied, or assumes any legal liability or responsibility for the accuracy, completeness, or any third party's use or the results of such use of any information, apparatus, product, or process disclosed, or represents that its use would not infringe privately owned rights. Reference herein to any specific commercial product, process, or service by trade name, trademark, manufacturer, or otherwise, does not necessarily constitute or imply its endorsement, recommendation, or favoring by the United States Government or any agency thereof or its contractors or subcontractors. The views and opinions of authors expressed herein do no necessarily state or reflect those of the United States Government or any agency thereof. 
Civilian Radioactive Waste Management System

Management and Operating Contractor

\section{Waste Package Operations FY-99 Closure Methods Report \\ TDR-EBS-ND-000002 REV 00 \\ September 1999}

PREPARED BY:

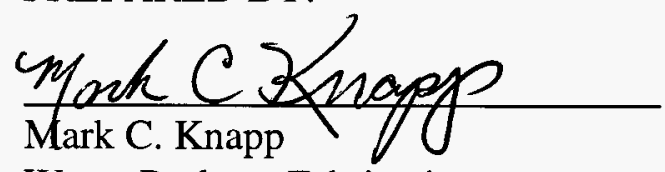

Waste Package Fabrication

Management and Operating Contractor

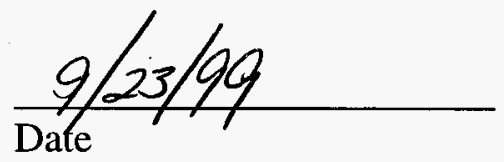

CHECKED BY:

Acott M bennett

Scott M. Bennett

$09 / 23 / 99$

Waste Package Design

Date

Management and Operating Contractor

\section{APPROVED BY:}

Heagh A. Benton to Jerry A. Cogar

$9 / 23 / 99$

Task Manager, Waste Package Fabrication

Management and Operating Contractor

Date

APPROVED BY:

Hugh A. Benton

Hugh Al Benton

$9 / 23 / 99$

Operations Manager, Waste Package Operations

Management and Operating Contractor 
INTENTIONALLY LEFT BLANK 


\section{CONTENTS}

\section{Page}

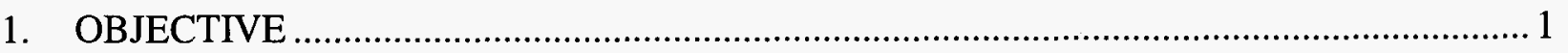

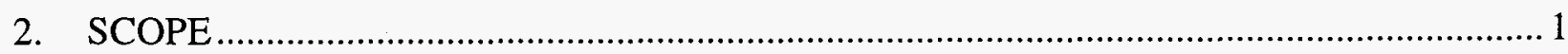

3. DESIGN REQUIREMENTS \& CRITERIA ......................................................... 2

3.1 PROJECT LEVEL REQUIREMENTS \& CRITERIA ................................... 2

3.2 QUALITY ASSURANCE REQUIREMENTS ................................................. 4

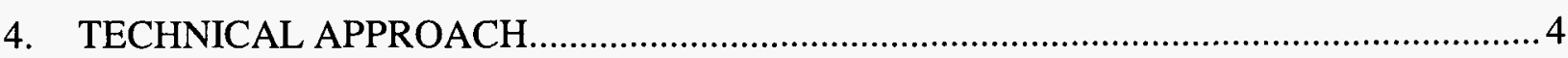

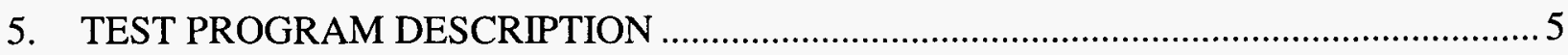

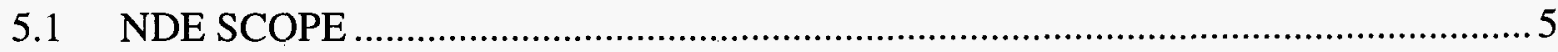

5.1.1 Surface and Volumetric NDE Performance ................................................5

5.1.2 Design and Build Two Test Samples for NDE Process Evaluation..................5

5.1.3 Alternate Surface Examination Techniques ............................................... 5

5.1.4 Couplant-Free Ultrasonic Examination Techniques ...................................5

5.1.5 Phased Array Ultrasonic Examination Techniques .................................... 7

5.1.6 Specifications for Integrated Welding and NDE Manipulator ........................ 7

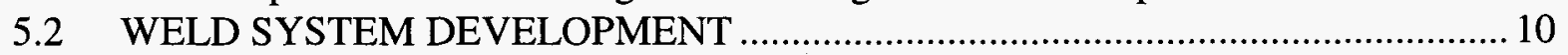

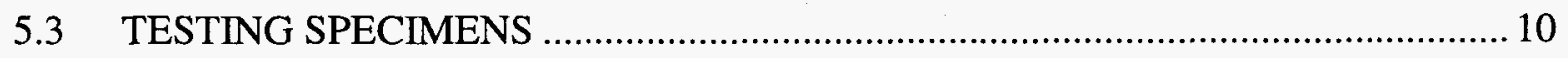

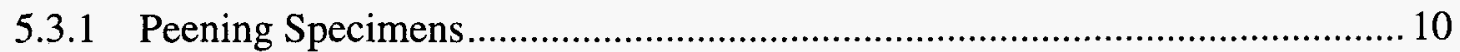

5.3.2 Welding of Corrosion and Residual Stress Coupons .................................... 10

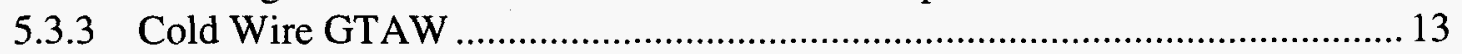

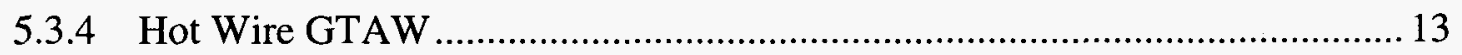

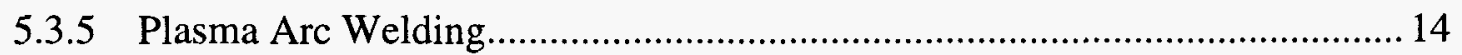

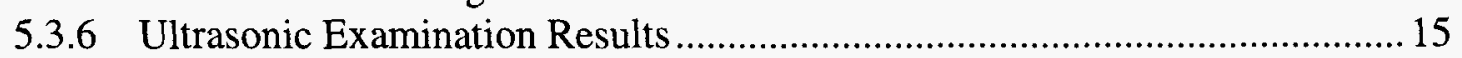

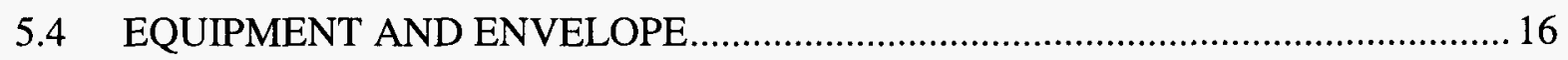

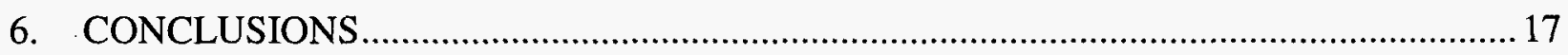

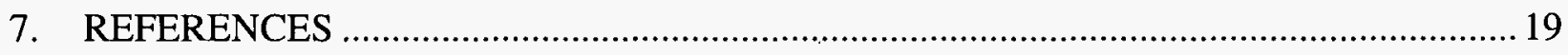

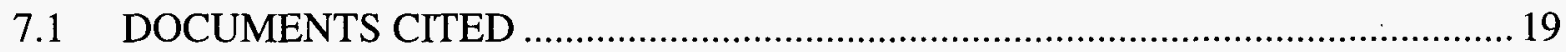

7.2 CODES, STANDARDS, REGULATIONS, AND PROCEDURES ...................... 19

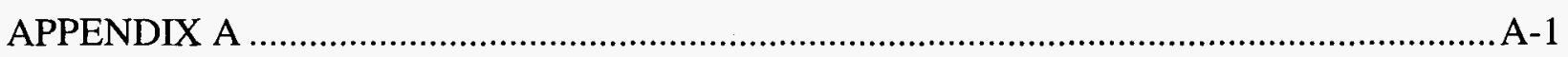


INTENTIONALLY LEFT BLANK 


\section{FIGURES}

Page

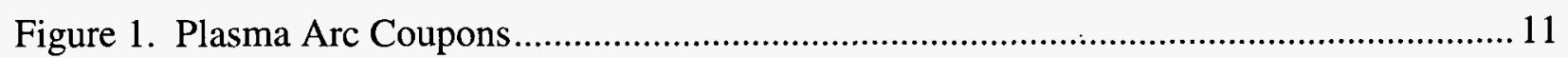

Figure 2. Hot Wire and Cold Wire GTAW Coupons................................................................ 11 
INTENTIONALLY LEFT BLANK 


\section{TABLES}

Page

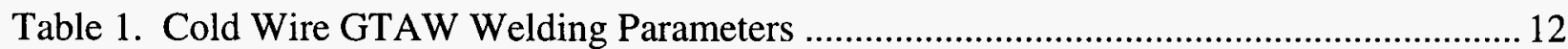

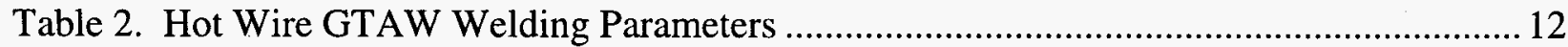

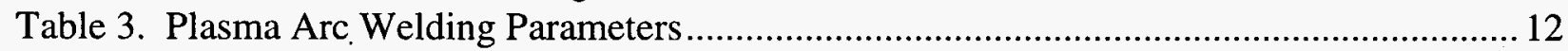

Table 4. Results of the Ultrasonic Examinations .................................................................... 16

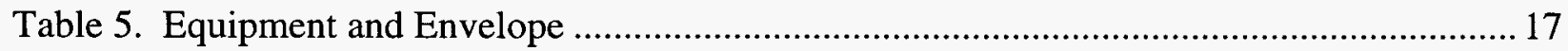


INTENTIONALLY LEFT BLANK 


\section{OBJECTIVE}

The waste package (WP) closure weld development task is part of a larger engineering development program to develop waste package designs. The purpose of the larger waste package engineering development program is to develop nuclear waste package fabrication and closure methods that the Nuclear Regulatory Commission will find acceptable and will license for disposal of spent nuclear fuel (SNF), non-fuel components, and vitrified high-level waste within a Monitored Geologic Repository (MGR).

Within the WP closure development program are several major development tasks, which, in turn, are divided into subtasks. The major tasks include: WP fabrication development, WP closure weld development, nondestructive examination (NDE) development, and remote in-service inspection development. The purpose of this report is to present the objectives, technical information, and work scope relating to the WP closure weld development and NDE tasks and subtasks and to report results of the closure weld and NDE development programs for fiscal year 1999 (FY-99).

The objective of the FY-99 WP closure weld development task was to develop requirements for closure weld surface and volumetric NDE performance demonstrations, investigate alternative NDE inspection techniques, and develop specifications for welding, NDE, and handling system integration. In addition, objectives included fabricating several flat plate mock-ups that could be used for NDE development, stress relief peening, corrosion testing, and residual stress testing.

\section{SCOPE}

Installation of the waste package closure lids will take place at the MGR surface facility following placement of the waste into the disposal container. Each of the closure lids must be separately welded into place and inspected, using remotely controlled equipment, to complete the envelope for each corrosion barrier. The primary development concerns were the combined choice of weld joint configurations and welding techniques to result in lowest possible post-weld tensile stress conditions and to investigate NDE techniques which can be used in a highly radioactive environment while delivering results with a high degree of confidence with respect to the integrity of the welds. The NDE techniques of interest specifically include methods of volumetric and surface weld examination which use non-contact processes, thereby reducing or eliminating the need to introduce potential contaminates in the weld cell.

The FY-99 WP closure weld development task scope of work includes all efforts required to develop and demonstrate a single welding process and NDE techniques which would be suitable to close the disposal container. The scope is narrowly defined intentionally (to investigate alternate NDE techniques and residual stress reduction through weld techniques rather than the broader task of optimization) as it is expected that refinements in weld and NDE processes will be realized as design and material requirements are finalized. The scope of work included the following tasks:
a. development of performance based NDE specification
b. design and build two test samples for NDE process evaluation
c. investigate alternate surface examination techniques
d. investigate couplant-free ultrasonic examination techniques 
e. investigate phased array ultrasonic techniques

f. develop a specification for integrated welding and NDE manipulator

g. develop a weld system interface control specification

h. fabricate peening specimens

i. fabricate corrosion specimens

j. fabricate residual stress specimens

k. determine equipment and envelope requirements

\section{DESIGN REQUIREMENTS \& CRITERIA}

\subsection{PROJECT LEVEL REQUIREMENTS \& CRITERIA}

The waste package closure weld development program, which is part of the larger engineering development program for waste package manufacturing, directly supports the disposal container design by demonstrating that such prototypic welds can be successfully performed.

Waste package/disposal container project level requirements are identified in Section 3 of the Monitored Geologic Repository Requirements Document (MGR-RD) (OCRWM 1999a). Project level requirements flow down from the MGDS-RD to the System Description Documents (SDDs) (CRWMS M\&O 1999a and 1998) as design criteria.

The criteria provided in this section are the only technical input to this report. The other input documents listed in Appendix A are for reference only. The to be determined/verified (TBX) notations in the criteria will not be carried forward to the conclusions of this report based on the rationale that the conclusions derived by this report are developmental in nature and require no further confirmation.

3.1.1 The disposal container SDD criteria applicable to the waste package/disposal container closure weld development task are the same for each of the SDDs. These criteria are listed here once:

3.1.1.1 "The disposal container shall be designed such that no more than 1 percent of all waste packages breach during the first 1,000 years after emplacement (breaching is defined as an opening through the wall of the waste package through which advective or diffusive transport of gas or radionuclides can occur)."

[Uncanistered SNF Disposal Container SDD Par. 1.2.1.3]

3.1.1.2 "The disposal container shall be designed such that for 10,000 years after permanent closure of the repository the release rate of any radionuclide from all waste packages shall not exceed one part in 100,000 per year of the inventory of that radionuclide calculated to be present at 1,000 years following permanent closure; provided, that this requirement does not apply to any radionuclide which is released at a rate less than 0.1 percent of the calculated total release rate limit. The calculated total release rate limit shall be taken to be one part in 100,000 per year of the inventory of radioactive waste, originally emplaced in the underground facility, that remains after 1,000 years of radioactive decay."

[Uncanistered SNF Disposal Container SDD Par. 1.2.1.4] 
The waste package lids and the lid closure welds are designed to be thicker than the corresponding inner and outer barrier nominal wall thicknesses to ensure ample thicknesses of sound material in the closure weld areas, thereby assuring barrier integrity. The closure weld development program directly supports disposal container design by demonstrating that such prototypic welds can be successfully performed using a high-quality weld process. The development program also supports other criteria (structural, handling, etc.) in the disposal container SDDs; however, because it is an indirect relationship, these criteria are not listed individually.

The Disposal Container Handling System Description Document (DCHSDD, CRWMS M\&O 1998) criteria applicable to the waste package/disposal container (DC) closure weld development task are:

3.1.2.1 "The system shall provide features to sample, measure, and monitor the disposal container temperature, radiation levels, and gas contents prior to and during welding operations. (TBD-226)"

[DCHSDD Par. 1.2.1.15]

3.1.2.2 "The system shall clean the disposal container inner and outer lid weld preparation surfaces to TBD-344."

[DCHSDD Par. 1.2.1.16]

3.1.2.3 "The system shall inert disposal containers as follows: gas type, pressure, and duration are TBD-227."

[DCHSDD Par. 1.2.1.17]

3.1.2.4 "The system shall perform closure welds for the disposal container (i.e., inner and outer lids) in accordance with ASME Boiling and Pressure Vessel (B\&PV) Code-1996; Section III, Division I, subsection NB, for Gas Tungsten Arc Welding with the limits defined in Table 1-8."

Table 1-8. Disposal Container Lid Welding Parameters

\begin{tabular}{|l|l|l|}
\hline Weld Parameters & \multicolumn{1}{|c|}{ Inner Lid Weld } & Outer Lid Weld \\
\hline Minimum weld thickness & $25 \mathrm{~mm}$ (TBV-443) & $110 \mathrm{~mm}$ (TBV-443) \\
\hline Continuous weld length (multipass) & 360 degrees & 360 degrees \\
\hline
\end{tabular}

[DCHSDD Par. 1.2.1.18]

3.1.2.5 "The system shall confirm the quality of the disposal container closure welds (i.e., inner and outer lids) by performing ultrasonic tests (UT) and visual tests (VT), which are nondestructive examinations and inspections, in accordance with the applicable ASME B\&PV Code requirements. Acceptance levels for UT are in accordance with ASME B\&PV Code-1996, Section III, Article NB, Article NB-5330. Acceptance levels for VT are in accordance with ASME B\&PV Code, Section III, division 1, Article NF-5360."

[DCHSDD Par. 1.2.1.19]

3.1.2.6 "The DC welding system shall be designed to prevent a burn-through of the inner DC lid."

[DCHSDD Par. 1.2.1.20] 
3.1.2.7 "The system shall be designed for a weld rejection rate of TBD-229."

[DCHSDD Par. 1.2.1.12]

3.1.2.8 "The system shall be designed to limit welding vapors to TBD-228."

[DCHSDD Par. 1.2.1.11]

3.1.2.9 "The system shall be designed to limit welding material deposition on the outer surface of the disposal container to TBD-228."

[DCHSDD Par. 1.2.1.21]

The waste package engineering development program does not directly satisfy the criteria for the DCHSDD (i.e., lid thickness); however, the information included herein is provided to the Repository Surface Design group. The information generated as a result of the development program specific to the weld system will be provided to and used by Surface Design to meet the DCHSDD criteria.

\subsection{QUALITY ASSURANCE REQUIREMENTS}

This report was prepared in accordance with AP-3.11Q, Technical Reports. The information provided in the report is to be indirectly used in the evaluation of the MGR waste package and engineered barrier segment. The waste package and engineered barrier segment have been identified as items important to radiological safety and waste isolation in the QAP-2-3 evaluation entitled Classification of the Preliminary MGDS Repository Design (CRWMS M\&O 1999b). The Waste Package Operations responsible manager has evaluated the report development activity in accordance with QAP-2-0 Conduct of Activities. The Activity Evaluation WP Engineering and Fabrication (CRWMS M\&O 1999c) evaluation has determined the preparation and review of the document is subject to Quality Assurance Requirements and Description (QARD) (OCRWM 1998) controls. There is no determination of importance evaluation developed in accordance with Nevada Line Procedure, NLP-2-0, Determination of Importance Evaluations, since the report does not involve any field activity.

\section{TECHNICAL APPROACH}

The development testing was conducted by Framatome Technologies Inc. (FTI) of Lynchburg, VA under their Safety Related Quality Assurance program which was approved by a Supplier Evaluation Report (OCRWM 1999b). The development program was conducted under the guidance of the Waste Package Operations FY-99 Closure Weld Development Technical Guidelines Document (CRWMS M\&O 1999d). 


\section{TEST PROGRAM DESCRIPTION}

\subsection{NDE SCOPE}

\subsubsection{Surface and Volumetric NDE Performance}

This task involved the development of a specification, Performance-Based Ultrasonic Examination Requirements for Waste Package Closure Welds (FTI 1999a), to assess the effectiveness of ultrasonic examinations of waste package closure welds and provide requirements for qualification of UT equipment, procedures, and personnel to perform these examinations. Waste package closure welds will require a surface and volumetric examination to assure weld integrity and to assure that the welding process did not adversely affect the adjacent base metal. Over the past 10 years, NDE requirements for applications in commercial nuclear reactors have shifted from prescriptive fabrication type standards to performance-based NDE. Performance-based NDE provides high confidence in the integrity of the welds examined because the examination techniques have been proven effective by demonstration on flawed and non-flawed mock-ups representative of the flaws of concern and the components to be examined. With this approach, not only can the flaw detection rates (percentage) and flaw sizing accuracy be measured, but the false-call (false-positive) rates can be assessed.

\subsubsection{Design and Build Two Test Samples for NDE Process Evaluation}

This task involved the fabrication of two mock-ups containing flaws of known dimensions to be used in assessment of NDE methods applicable to the waste package closure welds. These mock-ups are constructed of the same materials and weld joint design used for the FY-99 welding project (Alloy 22 and titanium). The mock-ups contain welding flaws of known dimension and include lack of fusion, porosity, and crater cracking. The target flaw size for this project is $5 \mathrm{~mm}$. The mock-ups contain flaws slightly above and below this range in order to be able to assess the NDE capability. Due to the late delivery of the mock-ups, a thorough ultrasonic examination could not be performed in time for the results to be included in this report. However, initial scanning using manual UT techniques indicate that all of the lack of fusion flaws can be easily detected in the titanium and Alloy 22 materials.

\subsubsection{Alternate Surface Examination Techniques}

This task involves the investigation of alternate surface examination techniques as a replacement to liquid penetrant examination in order to avoid production of hazardous waste. The alternate techniques included methods such as eddy current, thermal imaging, and Magneto-Optic Imaging. The mock-ups to be used for this task were the ones developed in Section 5.1.2; however, due to the late delivery of these mock-ups, the tests could not be conducted in time for this report. It is recommended that this task be performed during the next year's development program.

\subsubsection{Couplant-Free Ultrasonic Examination Techniques}

The objective of this task is to evaluate alternative UT inspection techniques that do not require couplant. The alternative techniques evaluated included Electro-Magnetic Acoustic Transducers (EMAT), EMAT with phased array, laser excitation, laser excitation and reception, and thermal imaging. 
EMAT induces eddy currents in the material in the presence of a strong magnetic field to induce ultrasound by means of the Lorenz force. In addition to the advantage of couplant free operation, the EMAT technology has the ability to generate propagation modes not available with piezo-electric transducers. The most important of these modes is the horizontal shear mode. This technique is highly dependent on the conductivity and the ferromagnetic properties of the material and has been successfully used on aluminum, where the conductivity is high, or on ferritic steels, where moderate conductivity is found in conjunction with high ferromagnetism.

Austenitic steels, however, have lower conductivity, typically $1 \%$ that of copper, and near zero ferromagnetism. For some time it had been assumed that EMAT techniques could not be used for these materials. However, recent research has found that it is possible to use the phased array technology with multiple EMAT transducers to achieve a usable signal. In this application, the phased pulsing of the transducers is used to enhance the signal above what could be achieved with a single transducer. With a usable signal strength, the horizontal shear propagation mode allows better penetration of the weld material.

Hybrid laser-EMAT systems use laser pulses to excite ultrasonic waves into material, with the returning signal detected by a standard EMAT transducer. As with the standard EMAT technology, the receiver will work best on highly conductive or ferromagnetic materials. Without the enhancement of either the horizontal shear propagation mode or the phased array technology, the hybrid laser-EMAT system would not appear to be as applicable to the austenitic materials.

Laser Emission-Laser Reception systems use the laser pulse to excite ultrasonic signal in the material. The return signal is detected as surface vibration with a laser interferometer. The greatest advantage of this technique is its ability to follow complex geometries. The primary limitation of this technology is that it only readily generates a normal (0-degree) pressure wave unless dealing with thin materials. Because of the lack of an angle beam mode, there may be limitations on the areas that can be reached for anything but extended open surfaces. Commercial systems are available.

The thermal wave imaging method maps the response of the material surface to fast thermal transients. The presence of flaws or other discontinuities at or near the surface cause changes in the thermal decay. These differences in thermal decay rates are used to form images of the discontinuity. The impulse for the thermal transient is often a laser pulse, but in the case of welding, the welding torch itself can be the source. The thermal wave technique has some sensitivity to near subsurface flaws; its sensitivity decreases exponentially with depth, much as does eddy current testing. As such, it would appear to be excluded by the primary assumption that the selected techniques should provide volumetric examinations. However, if the welding torch is used as the source for the thermal transient, this method can be used as a real-time monitor of the welding process on each pass. This requires a closed-loop coupling between the welding and imaging system.

Two technologies, phased array-EMAT and laser based ultrasonics, are mature enough technologies to warrant further evaluation, with primary emphasis on the EMAT technology. These techniques would be used in much the same manner as conventional UT in that the inspection would occur after the weld was complete. The other technique of interest is the thermal wave imaging. The greatest 
advantage for this technique would be as a continuous inspection during the welding process. The primary question for this method is the ability of the proposed welding system to make use of such a closed loop inspection system.

This task consisted of two phases. The first task included a scoping evaluation of the technologies including EMAT and laser-generated ultrasound. The results of the evaluation suggest that the use of EMAT is the most promising couplant-free ultrasonic method. However, a direct comparison to conventional ultrasonic methods is required. Phase two would involve application of the most promising technologies to the mock-ups developed in Section 5.1.2. This would provide a direct comparison to evaluate these technologies.

\subsubsection{Phased Array Ultrasonic Examination Techniques}

This task is intended to evaluate the effectiveness of using phased array ultrasonic examination techniques to assess improved effectiveness and efficiency of ultrasonic examination of the closure welds compared to conventional ultrasonic examination. The mock-ups developed in Section 5.1.2 were to be used for this evaluation; however, due to the late arrival of the mock-ups, this was not completed in time for inclusion in this report. It is suggested that this be task be rescheduled to next year's development program.

\subsubsection{Specifications for Integrated Welding and NDE Manipulator}

This task involved the preparation of a specification that outlines tool controller issues associated with performing automated and remote NDE applications. This document discusses the various types of control systems available and considerations for the selections of various controller designs that are compatible with "low-noise" environments required for these NDE applications.

This specification is concerned with the interface between the tooling hardware design and the motion control system. The intent is to summarize the tooling control options currently available to the tool designer. The general characteristics of the interface are as follows:

- The interface must provide controlled motion giving repeatable scan speeds and step increments. Manual control is not sufficient for data acquisition.

- The system must provide near real-time reporting of the scanner position as input to the welding and data acquisition processes.

A diverse range of controllers are currently available and must be considered for the applications required for closure welding and NDE processes. Because of the various applications within the system, selecting one or two types/kinds of controllers is not practical. Each individual application needs to be evaluated for the type of controller best suited for that application. The tool designer must select a tooling control based on the needs and constraints of the application. The types of controllers currently available include stepper motors, analog demand, position integral derivative (PID) analog controllers, and PID with coordinated motion. Each type of controller has strengths and limitations. 
The stepper motor controller is attractive because it is the simplest tool to control; just send a request for a number of steps. In addition, there is no need for any active control to hold a given position. In actual implementation, the control problem is more complicated. Without the addition of separate passive encoders, this would be an open loop without feedback. It is far too easy for the motor to lose a couple of steps on each motion, which results in significant errors during a multi-stroke raster scan. The other limitations are power and speed. High power stepper motor controllers tend to radiate a lot of electrical noise. That noise is unacceptable during data acquisition. The speed is further limited due to the pulse nature of the motor steps. The controller has a limitation on the rate of sending steps, and the motor has a torque curve that decreases with increasing step rate.

Design Inputs

- Step resolution, must meet resolution needs of the scan increments

- Encoder resolution, should be equal to or better than step resolution

- Maximum current

- Maximum step rate

Signal Connections

- From controller to motor/encoders: multi-wire cabling

- From controller to operator's station: serial or local area network (LAN), either can be extended by fiber optics

- From controller to acquisition: sync pulse or encoder ouput

Controller Location

- Less than $500 \mathrm{ft}$ from the scanner

Simple analog demand controllers, as well as the two following controllers, use analog servo-motor controllers. These controllers have much lower electrical noise for a given motor torque. Further, servo-motors have a greater torque for a given package size. The result is that for a given application, the servo-motor has greater torque and power than the stepper motor; however, the servo-motor must be actively controlled. For the stepper motor, the acquisition system only needs to check the final position after a motion is requested, while for a servo-motor, the position must be monitored during the motion. The simple analog demand controllers use simple, minimal electronics. The controller hardware itself has an open-loop, speed demand. The system uses the acquisition hardware to read the encoder and provides a coarse, closed loop control on position. The controller hardware can synthesize an encoder signal from motor commutation. This controller cannot react to variations in mechanical resistance or load. Changes in the inertia of the tool from one application to the next are also a problem. This controller cannot implement a PID loop because the controller uses the encoder information from the acquisition system. The rate of acquisition will not be high enough to support a PID control. 
Design Inputs

- Encoder resolution

- Maximum current

- Maximum motor speed

- Minimum motor speed (stall speed based on torque curve and mechanical resistance)

Signal Connections

- From controller to scanner: cabling for motor power and encoder signals

- From controller to operator's station: serial that can be extended by fiber optics

- From controller to acquisition: encoder output

Controller Location

- Within $500 \mathrm{ft}$ of the scanner

PID analog controllers provide truly closed loop control of both speed and position. This enables the controller to handle a much wider range of conditions. This improved control comes at the cost of requiring real time computer control of the motion. The controller must directly read the encoders and react to the changes in resistance, load, etc. This requires a larger, more complicated, more expensive computer. In addition, this tool requires a trained tooling operator to establish and adjust the PID parameters.

Design Inputs

- Motor characteristics of torque and power

- Tool inertia

- Current limits

- Position sampling rates

Signal Connections

- From controller to scanner: cabling for motor power and encoder signals

- From controller to operaror's station: LAN

- From controller to acquisition: encoder output, LAN

Controller location

- Within $500 \mathrm{ft}$ of the scanner

PID controllers with coordinated motion are the closest to the ideal of a universal controller. It is highly adaptive to very general problems of scanning motion geometries. This adaptability comes at the cost of a tool with a high degree of complexity in design, implementation, and operation. This really should be the controller of last resort, to be used only when none of the above will work. 
The design inputs for this style controller are really beyond the scope of this document.

The type of controller used for a particular application must be based on the design requirements of the application as well as the advantages and limitations of the controllers. As system requirements become more well defined, these selection criteria will be evaluated on a case by case basis and the appropriate hardware employed for each application.

\subsection{WELD SYSTEM DEVELOPMENT}

This task involved the development of interface control specifications required for the Surface Facilities Operations/Waste Package Operations closure weld interface in the hot cell welding configuration. This specification describes the system components and their interactions as part of a system diagram. The specification, System Diagram of the Yucca Mountain Waste Package Closure System (FTI 1999b) identifies the system's main components and provides a road map for the integration of the system.

\subsection{TESTING SPECIMENS}

\subsubsection{Peening Specimens}

A scoping non-Q study was used to evaluate the possibility of using laser peening to reduce surface tensile stresses on welded joints. Two 1 inch thick Alloy 22 plates were welded with narrow groove Hot Wire GTAW. These plates were fully restrained using carbon steel strongbacks to prevent distortion in the joints. Lawrence Livermore National Laboratory (LLNL) provided the material and designated the weld groove joint geometry. The plates were then returned to LLNL to complete the laser peening experiment.

\subsubsection{Welding of Corrosion and Residual Stress Coupons}

The welding requirements for these coupons were not related to the type of coupon being welded. The type of coupon only specifies the type of test that will be performed after the completion of welding and NDE. Three processes were used to weld the Residual Stress and Corrosion Coupons. The purpose of the coupons was to compare and contrast Plasma Arc Welding with Cold Wire GTAW and Hot Wire GTAW. The welding procedures and joint designs were based on the process used for each coupon. Both types of coupons used the same procedure and joint designs for each individual process. All of the coupons were either a 7/8 inch full penetration Alloy 22 weld or a 5/8 inch full penetration titanium weld. The following figures show the joint design for the coupons, and the following tables summarize of the welding parameters used for each process and material used. 


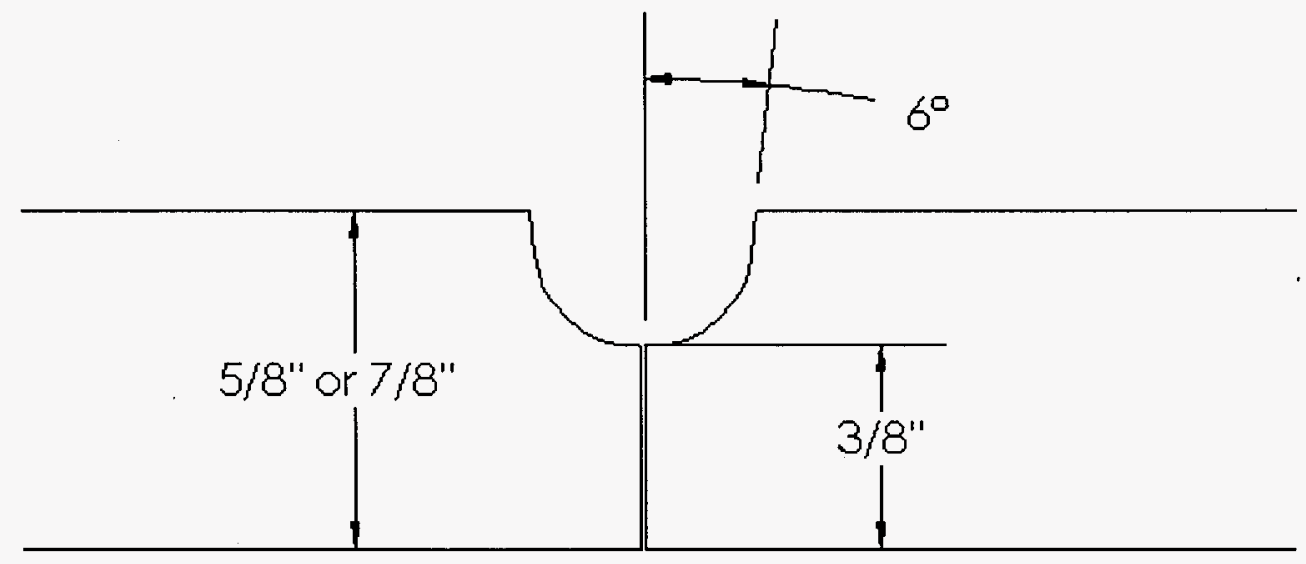

Figure 1. Plasma Arc Coupons

Figure 1 shows the basic weld geometry used for the plasma arc coupons with dimensions. Titanium plates were $5 / 8$ inch thick and the Alloy 22 plates were $7 / 8$ inch thick.

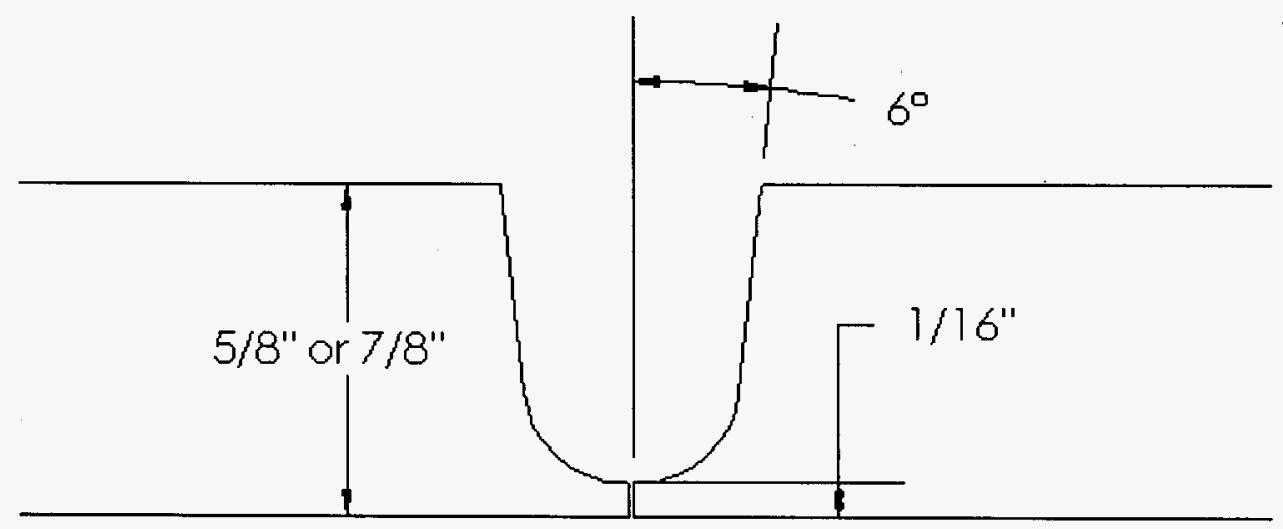

Figure 2. Hot Wire and Cold Wire GTAW Coupons

Figure 2 shows the basic weld geometry used for the Hot Wire and Cold Wire GTAW coupons with dimensions. Titanium plates were 5/8 inch thick and the Alloy 22 plates were $7 / 8$ inch thick. 
Table 1. Cold Wire GTAW Welding Parameters

\begin{tabular}{|l|l|}
\hline \multicolumn{1}{|c|}{ Parameter } & \\
\hline Torch Amperage & $275 / 175$ \\
\hline Torch Voltage & $11.5-12$ \\
\hline Travel Speed (IPM) & 4.0 \\
\hline Wire Feed Speed (IPM) & $60-110 / 30-54$ \\
\hline Shield Gas Flow (CFH) & 50 \\
\hline Trailing Gas Flow (CFH) & 50 \\
\hline Shielding Gas Composition & $75 \% \mathrm{He} / 25 \% \mathrm{Ar}$ \\
\hline
\end{tabular}

IPM = inches per minute $\mathrm{CFH}=$ cubic feet per hour

Table 2. Hot Wire GTAW Welding Parameters

\begin{tabular}{|l|l|l|}
\hline \multicolumn{1}{|c|}{ Parameter } & \multicolumn{1}{c|}{ Alloy 22 } & \multicolumn{1}{c|}{ Titanium } \\
\hline Torch Amperage & $330-335$ & $305-330$ \\
\hline Torch Voltage & $12.5-13.0$ & $10.5-11.0$ \\
\hline Travel Speed (IPM) & 8 & $6.4-8$ \\
\hline Wire Feed Speed (IPM) & 160 & $120-160$ \\
\hline Shield Gas Flow (CFH) & 40 & 45 \\
\hline Trailing Gas Flow (CFH) & 40 & 50 \\
\hline Shielding Gas & $75 \% \mathrm{He} / 25 \% \mathrm{Ar}$ & $99.9 \%$ Argon \\
\hline Hot Wire Voltage & $2-3$ & $2-3$ \\
\hline Hot Wire Amperage & $55-65$ & $55-65$ \\
\hline
\end{tabular}

Table 3. Plasma Arc Welding Parameters

\begin{tabular}{|c|c|c|}
\hline Parameter & Titanium Keyhole & Titanium Melt-in \\
\hline Torch Amperage & $200 / 100$ & $300 / 150$ \\
\hline Torch Voltage & Locked at fixed distance & Locked at fixed distance \\
\hline Travel Speed (IPM) & 4.0 & 5.5 \\
\hline Wire Feed Speed (IPM) & $\mathrm{N} / \mathrm{A}$ & 60 \\
\hline Shield Gas Flow (CFH) & 40 & 40 \\
\hline Shield Gas & Argon & Argon \\
\hline Plasma Gas Flow (CFH) & 6.5 & 0.5 \\
\hline Plasma Gas & $50 \% \mathrm{Ar} / 50 \% \mathrm{He}$ & $50 \% \mathrm{Ar} / 50 \% \mathrm{He}$ \\
\hline Trailing Gas Flow (CFH) & 30 & 30 \\
\hline Trailing Gas & Argon & Argon \\
\hline
\end{tabular}


The introduction of Alloy 22 and titanium materials and different welding processes than used in previous year's development programs required new procedures. Two new procedures were developed to complete the titanium coupons. These two procedures are for Plasma Arc Welding and Hot Wire GTAW. A procedure to Plasma Arc Weld Alloy 22 was unable to be developed due to limitations of the process for welding thick joints.

\subsubsection{Cold Wire GTAW}

The Cold Wire GTAW process has been used in the FY-97 development program to weld a narrow groove geometry. The welding of these coupons was relatively easy because procedures had already been developed. All Alloy 22 plates used for the coupons were restrained using carbon steel strongbacks. These were thick plates welded to the back of the Alloy 22 plate with Alloy 22 welding rods.

\subsubsection{Hot Wire GTAW}

Hot Wire GTAW applies electrical current to the filler metal to help melt in the wire, thus achieving higher wire feed rates than Cold Wire GTAW. The process was used in the FY-98 development program and has been proven to produce excellent results on the welded samples. Alloy 22 coupons were successfully welded without difficulty using procedures developed in the FY-98 program. However, challenges were encountered while completing the titanium welds.

The most significant difference between welding Alloy 22 and welding titanium is that titanium requires much better shielding to produce acceptable welds. Most of the welds produced had some level of surface contamination. It is very easy to see a lack of shielding in titanium weld by examining the color of the welded surface. A silver or gray color indicates the area was totally shielded from contamination. As the surface becomes contaminated, the metal will turn gold, then red and blue with increased contamination. These levels of surface contamination are thought to be acceptable if they are brushed off between passes. FTI has not ultrasonically tested any titanium weldments, but welds with these levels of contamination did pass transverse bend tests and performed adequately on tensile tests. If the weld has a flaky white appearance, the contamination has probably affected more than the surface, and the weld is probably unacceptable. Trailing gas shielding boxes were used to weld titanium; these boxes adequately shielded the titanium.

Most of the problems experienced were with wire jamming. The titanium wire (ERTi-7) is very soft and malleable when compared to the Alloy 22 wire. This characteristic of the wire caused a problem at high feed rates. The location where the wire contacted the molten weld pool was unpredictable because the wire would move from side to side as well as up and down. When the wire fed into a solidified area, it caused the feeder to jam. This problem can be fixed by designing a better wire feeding system. Because the titanium coupons were required to be fully restrained and titanium is not readily weldable to dissimilar metals, a slide-on carbon steel strongback was designed for these coupons. Five strongbacks were used over the 32 inch plates to prevent distortion. With proper shielding, titanium was readily welded with the process except for wire feeding problems. 


\subsubsection{Plasma Arc Welding}

Plasma Arc Welding (PAW) is beneficial to the closure lid welding because it can produce faster welds with less distortion and reduced residual stresses. These benefits are accomplished by PAW's ability to fully penetrate a $3 / 8$ inch or greater root pass using a keyhole technique. The process uses a constricted orifice that produces a hotter, more concentrated arc. A narrow stream of plasma gas flows through the constricted orifice at a high velocity and punches a keyhole through the molten base metal. As the weld progresses, the molten metal solidifies behind the keyhole leaving a fully penetrated weld with an acceptable backside and root face bead.

Keyhole welds were made with Alloy 22 and titanium with a $3 / 8$ inch penetration in a single pass. With additional development, $1 / 2$ inch keyhole welds in these materials may be possible. Because of the low density of titanium it could be possible to produce $3 / 4$ inch keyhole welds. Stainless steel is limited to $3 / 8$ inch keyhole. Several attempts were made to keyhole a $1 / 2$ inch section, but none were successful.

The Alloy 22 coupons were unable to be completed because the joint design required a minimum arc length of 9/16 inch for the keyhole pass. With this long arc gap, the process was very unstable and did not consistently produce a sound root pass. Using this long arc length on the second pass while feeding wire did not allow smooth flow of the wire in the joint and thus left holes and side wall lack of fusion. For this reason, the PAW Alloy 22 Corrosion and Residual Stress coupons were unable to be completed. A successful keyhole was welded from the backside of the joint. By welding on this side, a shorter arc length was able to be used. This work was for information purposes only; therefore, no procedure was written for it.

Titanium welding with PAW was successful, and procedures were developed to weld the coupon. The welding of the PAW titanium coupon was completed, but the plasma torch was experiencing problems while completing the keyhole pass. This probably left several indications in the full penetration weld. UT of this plate has not been completed at this time. This coupon was restrained with the same type of strongbacks used for the Hot Wire GTAW coupons. A purge chamber on the backside of the weld was added to the setup to completely shield the backside of the weld.

The plasma arc welding process in the keyhole mode is very sensitive to small environmental or parameter changes that can leave holes in the root pass of the weld. The arc sometimes becomes unstable. This could be caused by an inconsistent flow of plasma gas or by changing air flow patterns in the work area. A very small orifice was used to qualify the procedure to weld the titanium. A larger orifice could help reduce the sensitivity of the arc in the keyhole mode.

The use of PAW on closure lid welding has potential; however, more development is required to determine if the process will be beneficial for this application. In order to fully utilize PAW on thick sections, a narrow groove torch would need to be designed. The current torch design limits it to welding $3 / 4$ inch or thinner materials. The arc length becomes too long to successfully keyhole the root pass when used on thicker materials. A narrow groove torch design will enable a $3 / 8$ inch to $1 / 2$ inch keyhole root pass and then several filler passes to complete a thicker joint. Because plasma has so many variables, more time is needed to fully develop a good procedure to weld with this 
process. The current Welding Procedure Specifications and Procedure Qualifications do not consistently produce acceptable welds. Fit-up criteria for keyhole welds will be necessary to specify fit-up tolerances in the system diagram. Upslope and downslope of the plasma gas are also in need of further development. These parameters will leave a hole at the start and finish of the keyhole section if they are not set properly.

\subsubsection{Ultrasonic Examination Results}

As part of the FY-99 development program, the Alloy 22 and titanium welded plate samples were ultrasonically examined for determining weld integrity. The plates examined are the Alloy 221 inch plates and the titanium grade $7,5 / 8$ inch plates. Both the Alloy 22 and titanium plate samples were ultrasonically examined in the as-welded condition, i.e., full penetration welds with no grinding or machining of weld crowns or weld root.

Ultrasonic examination of the plate samples was performed in accordance with the American Society of Mechanical Engineers (ASME) Boiler and Pressure Vessel Code, Section III (ASME 1989a) and Section V, 1989 Edition (ASME 1989b). Each plate was ultrasonically examined using the Framatome designed "X/Y" scanner and data acquisition and analysis systems, Accusonex. The scanner was used for positioning the ultrasonic probe in a controlled manner relative to the weld axis. The scanner was attached to a stationary platform, and each plate was subsequently positioned adjacent to the scanner for performing the examination. The " $\mathrm{X} / \mathrm{Y}$ " coordinates of the scanner were oriented parallel and perpendicular to the weld axis respectively. As the probe was scanned over the plates surface, data was acquired at specified intervals. This data was subsequently filtered, digitized, and stored on optical media for storage and data analysis. After completion of data acquisition, the ultrasonic data was analyzed for weld defects, lack of fusion, porosity, etc. in accordance with the ASME Code, Sections III and V.

Currently, three Alloy 22 samples have been ultrasonically examined; specifically, two residual stress coupons and one corrosion coupon. Each plate was ultrasonically examined for indications oriented parallel, or near parallel, to the weld axis. This was accomplished by pointing the probe perpendicular to the weld axis. Three separate transducers were used for performing the examination, a $45^{\circ}$ shear wave, a $60^{\circ}$ shear wave, and a $70^{\circ}$ longitudinal wave. The $45^{\circ}$ and $60^{\circ}$ angles each used single-element $2.25 \mathrm{MHz}, 0.5$ inch diameter, composite probes. The $70^{\circ}$ angle used dual-element ( 0.3 inch x 0.6 inch per element) $5 \mathrm{MHz}$ probes. Since each plate coupon was required to be examined in the as-welded condition, the weld crown on each sample limited how closely the probe could get to the weld. To offset this limitation, the $45^{\circ}$ probe was used in both the half-vee and full-vee configurations (half-vee travels from the top surface to the bottom surface, full-vee travels from the top surface to the bottom and back to the top surface). The half-vee technique examined the base, or root area of the weld, and the full-vee technique examined the upper portion of the weld by bouncing the ultrasound off the inside diameter surface. The $60^{\circ}$ and $70^{\circ}$ angles supplemented the $45^{\circ}$ coverage with the $60^{\circ}$ providing coverage from the root upwards and the $70^{\circ}$ covering the upper part of the weld. Calibration of the ultrasonic system was performed using ASME Code calibration blocks, one for the Alloy 22 and one for the titanium material. 
Table 4. Results of the Ultrasonic Examinations

\begin{tabular}{|c|c|c|c|}
\hline Scan & Corrosion Plate Coupon & $\begin{array}{c}\text { Residual Stress } \\
\text { Coupon \#1 }\end{array}$ & $\begin{array}{c}\text { Residual Stress } \\
\text { Coupon \#2 }\end{array}$ \\
\hline 45 RS.Y+ & NRI & NRI & NRI \\
\hline 60 RS.Y+ & NRI & NRI & NRI \\
\hline $70 R L . Y_{+}$ & NRI & NRI & NRI \\
\hline $45 R S . Y_{-}$ & NRI & $\begin{array}{c}\text { Indication adjacent } \\
\text { to weld root }\end{array}$ & NRI \\
\hline $60 R S . Y_{-}$ & NRI & NRI & NRI \\
\hline 70RL.Y- & NRI & NRI & \\
\hline
\end{tabular}

$\mathrm{NRI}=$ No Recordable Indications

The unacceptable indication located in the residual stress coupon \#1 is a $54 \%$ distance amplitude correction (DAC) indication located adjacent to the root and measuring 3.2 inch in length. No through-wall measurement was taken since the amplitude was less than $100 \%$ DAC. By procedure this indication would be unacceptable if characterized as a crack, lack of fusion, or incomplete penetration. Most likely, being near the root the indication can be characterized as incomplete penetration.

\subsection{EQUIPMENT AND ENVELOPE}

The container closure system for welding the lids onto the containers is a complex system, but it is not beyond current manufacturing technology. At present, the configuration of the system can only be configured to a point because the type of material and configuration of the containers has not been fully defined. The material type affects the welding process, which in effect determines the welding equipment and the control of automating the process. Therefore, to specify equipment and vendors at this time is premature. However, the system can be defined in general terms and functionality. The specification, System Diagram of the Yucca Mountain Waste Package Closure System (FTI 1999b) describes these components and interactions in more detail. 
Table 5. Equipment and Envelope

\begin{tabular}{|c|c|c|}
\hline Equipment & Function & Comments \\
\hline $\begin{array}{l}\text { CCCS (Closure Cell } \\
\text { Control System) }\end{array}$ & $\begin{array}{l}\text { Controls all the } \\
\text { communications and } \\
\text { sequences to provide the } \\
\text { operator with real time } \\
\text { status and overrides all of } \\
\text { the sequence and sequence } \\
\text { steps }\end{array}$ & $\begin{array}{l}\text { This is obviously some type of controller. The hardware } \\
\text { components can be purchased off-the-shelf; however, } \\
\text { the configuration for the application is unique }\end{array}$ \\
\hline Turntable & $\begin{array}{l}\text { Positioning and welding } \\
\text { speed }\end{array}$ & $\begin{array}{l}\text { Facility System: There are companies such as K.N. } \\
\text { Aronson, Inc. that have been making large turntables for } \\
\text { welding for some time. This is a possible source, but it } \\
\text { may be special to cover all container types }\end{array}$ \\
\hline Bridge Crane & Delivers container to station & Facility System \\
\hline Lid Delivery System & $\begin{array}{l}\text { Delivers and positions lids } \\
\text { on containers }\end{array}$ & Facility System \\
\hline $\begin{array}{l}\text { Optical Inspection } \\
\text { System }\end{array}$ & $\begin{array}{l}\text { Inspects container for } \\
\text { debris, verifies position and } \\
\text { dimensions and determines } \\
\text { the condition of the weld } \\
\text { preps }\end{array}$ & $\begin{array}{l}\text { This can be comprised of components that are off-the- } \\
\text { shelf; however, there will be some customization for the } \\
\text { application }\end{array}$ \\
\hline $\begin{array}{l}\text { End-Effector Delivery } \\
\text { System. }\end{array}$ & $\begin{array}{l}\text { Positions the different end- } \\
\text { effectors to perform the } \\
\text { desired tasks }\end{array}$ & $\begin{array}{l}\text { Facility System: This system most likely will be an } \\
\text { industrial robot. However, until all the types of end- } \\
\text { effectors are designed, this can not be specified. The } \\
\text { likely choice for this robot is a gantry style because of its } \\
\text { flexibly, accuracy, and rigidity of locating components }\end{array}$ \\
\hline Welding End-Effector & $\begin{array}{l}\text { Performs the welding of the } \\
\text { lid to the container }\end{array}$ & $\begin{array}{l}\text { This end-effector can be comprised of components that } \\
\text { are off-the-shelf; however, there will be some } \\
\text { customization for the application }\end{array}$ \\
\hline Inspection End-Effector & $\begin{array}{l}\text { Performs visual and } \\
\text { volumetric inspections }\end{array}$ & $\begin{array}{l}\text { This end-effector can be comprised of components that } \\
\text { are off-the-shelf; however, there will be some } \\
\text { customization for the application }\end{array}$ \\
\hline Purge Seal End-Effector & $\begin{array}{l}\text { Used to back fill the } \\
\text { container, close the purge } \\
\text { port, and weld the seal plug }\end{array}$ & Seal/plug design needs to be finalized \\
\hline
\end{tabular}

\section{CONCLUSIONS}

The late start on the project and the long lead time for the current materials did not allow FTI to accomplish all the work required by the Technical Guidelines Document in the depth required. These tasks will continue to be performed until the end of the fiscal year and reported on in the FY-2000 closure document. As necessary, the work will continue in the next fiscal year. Many assumptions were made to complete this year's system diagram. More development in welding and NDE is required to accurately complete the system diagram so assumptions will not have to be made. If the design of the PAW narrow groove torch is successful in next year's workscope, PAW could be very beneficial to closure lid welding, saving time, and reducing residual stress.

Weld samples created in this year's program will allow a number of tests to be conducted by LLNL and other organizations. These include magnesium chloride, residual stress, as well as corrosion and aging tests. 
INTENTIONALLY LEFT BLANK 


\section{REFERENCES}

\subsection{DOCUMENTS CITED}

Civilian Radioactive Waste Management System (CRWMS) Management and Operating Contractor (M\&O) 1998. Disposal Container Handling System Description Document. BCB000000-01717-1705-00026 REV 00. Las Vegas, Nevada: CRWMS M\&O. ACC: MOL.19980910.0676

CRWMS M\&O 1999a. Uncanistered Spent Nuclear Fuel Disposal Container System Description Document. BBA000000-01717-1705-00004 REV 01. Las Vegas, Nevada: CRWMS M\&O. ACC: MOL.19990608.0160

CRWMS M\&O 1999b. Classification of the Preliminary MGDS Repository Design. B0000000001717-0200-00134 REV 01. Las Vegas, Nevada: CRWMS M\&O. ACC: MOL.19981103.0546

CRWMS M\&O 1999c. QAP-2-0 Activity Evaluation WP Engineering and Fabrication. Las Vegas, Nevada: CRWMS M\&O. ACC: MOL. 19990330.0490

CRWMS M\&O 1999d. Waste Package Operations FY-99 Closure Weld Development Technical Guidelines Document. BBA000000-01717-2500-00017 REV 00. Las Vegas, Nevada: CRWMS M\&O. ACC: MOL.19990511.0239

FTI 1999a. Performance-Based Ultrasonic Examination Requirements for Waste Package Closure Welds. Lynchburg, Virginia: FTI. ACC: MOL.19990903.0111

FTI 1999b. System Diagram of the Yucca Mountain Waste Package Closure System. Lynchburg, Virginia: FTI. ACC: MOL.19990903.0112

Office of Civilian Radioactive Waste Management (OCRWM) 1998. Quality Assurance Requirements and Description. DOE/RW-0333P REV 08. Washington D.C.: U.S. Department of Energy (DOE). ACC: MOL.19980601.0022

OCRWM 1999a. Monitored Geologic Repository Requirements Document. YMP/CM-0025 REV 3. DCN01. Las Vegas, Nevada: DOE. ACC: MOL.19990429.0228

OCRWM 1999b. Supplier Evaluation Report. Framatome Technologies Inc. Dated 6/21/99. Las Vegas, Nevada: DOE. ACC: MOL.19990712.0089

\subsection{CODES, STANDARDS, REGULATIONS, AND PROCEDURES}

ASME 1989a. ASME Boiler and Pressure Vessel Code. Section III, Rules for Construction of Nuclear Power Plant Components. Division 1 - Subsection NB. New York, New York: ASME. TIC: 232801

ASME 1989b. ASME Boiler and Pressure Vessel Code. Section V, Nondestructive Examination New York, New York: ASME. TIC: 245342 
APPENDIX A

\section{DOCUMENT INPUT REFERENCE SHEET}


INTENTIONALLY LEFT BLANK 


\section{OFFICE OF CIVILIAN RADIOACTIVE WASTE MANAGEMENT}

DOCUMENT INPUT REFERENCE SHEET

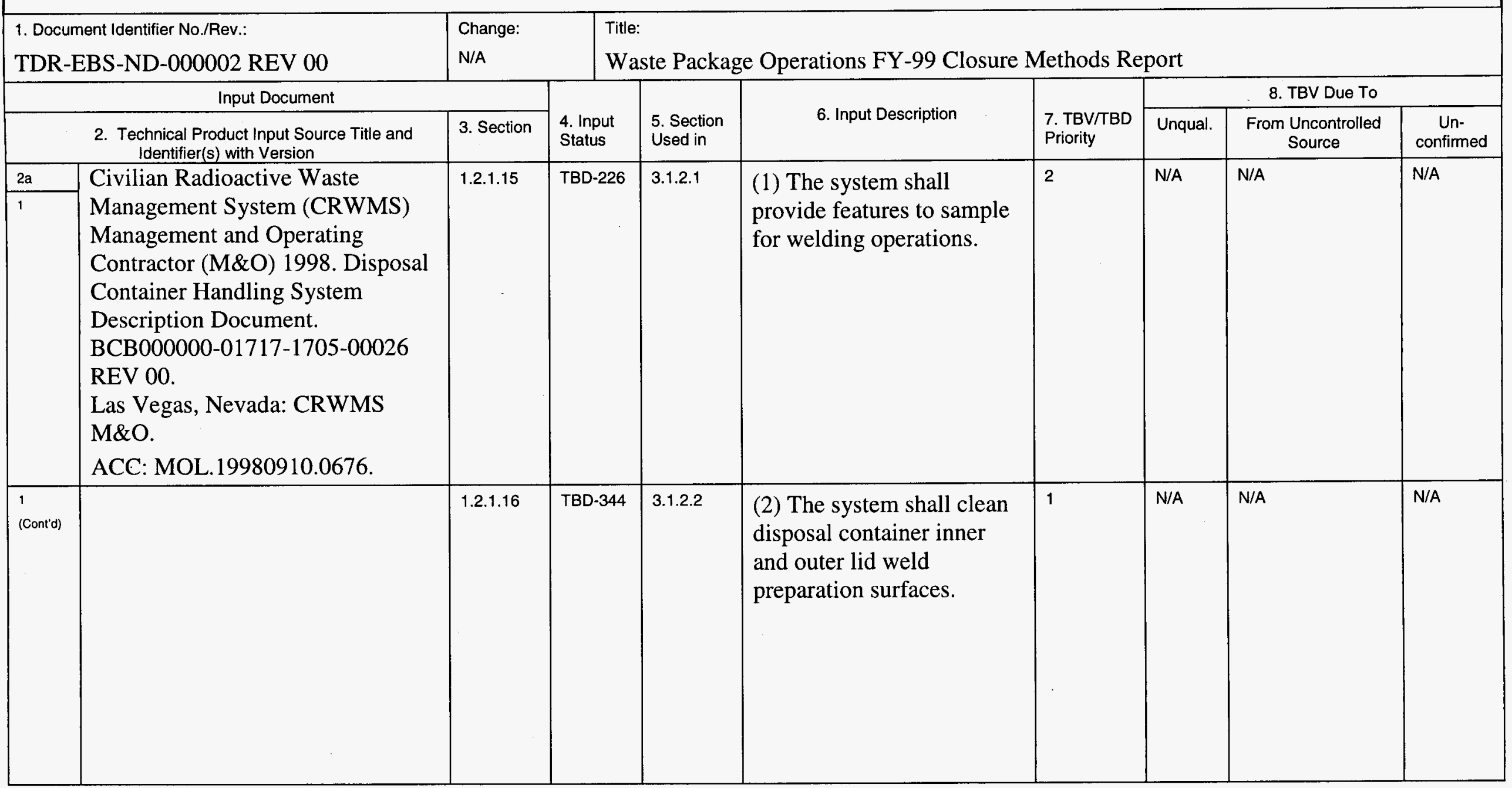




\section{OFFICE OF CIVILIAN RADIOACTIVE WASTE MANAGEMENT}

DOCUMENT INPUT REFERENCE SHEET

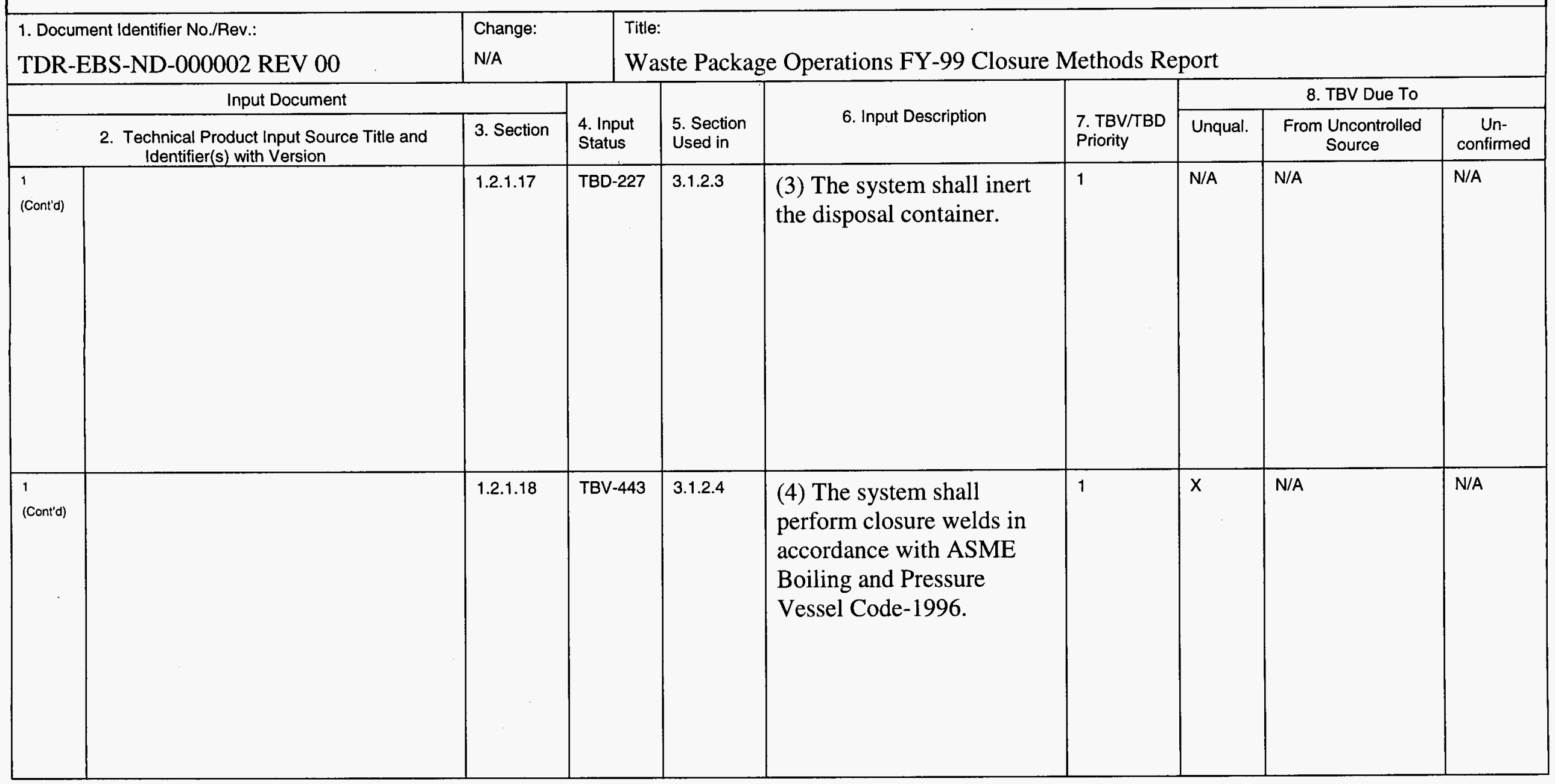




\section{OFFICE OF CIVILIAN RADIOACTIVE WASTE MANAGEMENT}

DOCUMENT INPUT REFERENCE SHEET

\begin{tabular}{|c|c|c|c|c|c|c|c|c|c|}
\hline \multicolumn{2}{|c|}{$\begin{array}{l}\text { 1. Document Identifier No./Rev.: } \\
\text { TDR-EBS-ND-000002 REV } 00\end{array}$} & $\begin{array}{l}\text { Change: } \\
\text { N/A }\end{array}$ & \multicolumn{7}{|c|}{$\begin{array}{l}\text { Title: } \\
\text { Waste Package Operations FY-99 Closure Methods Report }\end{array}$} \\
\hline \multicolumn{3}{|c|}{ Input Document } & \multirow[b]{2}{*}{$\begin{array}{l}\text { 4. Input } \\
\text { Status }\end{array}$} & \multirow[b]{2}{*}{$\begin{array}{l}\text { 5. Section } \\
\text { Used in }\end{array}$} & \multirow{2}{*}{ 6. Input Description } & \multirow[b]{2}{*}{$\begin{array}{l}\text { 7. TBV/TBD } \\
\text { Priority }\end{array}$} & \multicolumn{3}{|c|}{ 8. TBV Due To } \\
\hline & $\begin{array}{l}\text { 2. Technical Product Input Source Title and } \\
\text { Identifier(s) with Version }\end{array}$ & 3. Section & & & & & Unqual. & $\begin{array}{l}\text { From Uncontrolled } \\
\text { Source }\end{array}$ & $\begin{array}{c}\text { Un- } \\
\text { confirmed }\end{array}$ \\
\hline $\begin{array}{l}1 \\
\text { (Cont'd) }\end{array}$ & & 1.2 .1 .19 & $\mathrm{~N} / \mathrm{A}$ & 3.1.2.5 & $\begin{array}{l}\text { (5) The system shall } \\
\text { confirm the quality of the } \\
\text { disposal container closure } \\
\text { welds. }\end{array}$ & $N / A$ & $\mathrm{~N} / \mathrm{A}$ & $N / A$ & $N / A$ \\
\hline $\begin{array}{l}1 \\
\text { (Cont'd) }\end{array}$ & & 1.2 .1 .20 & N/A & 3.1 .2 .6 & $\begin{array}{l}\text { (6) The DC welding } \\
\text { system shall be designed to } \\
\text { prevent a burn-through of } \\
\text { the inner DC lid. }\end{array}$ & $\mathrm{N} / \mathrm{A}$ & N/A & $N / A$ & $\mathrm{~N} / \mathrm{A}$ \\
\hline
\end{tabular}




\section{OFFICE OF CIVILIAN RADIOACTIVE WASTE MANAGEMENT}

DOCUMENT INPUT REFERENCE SHEET

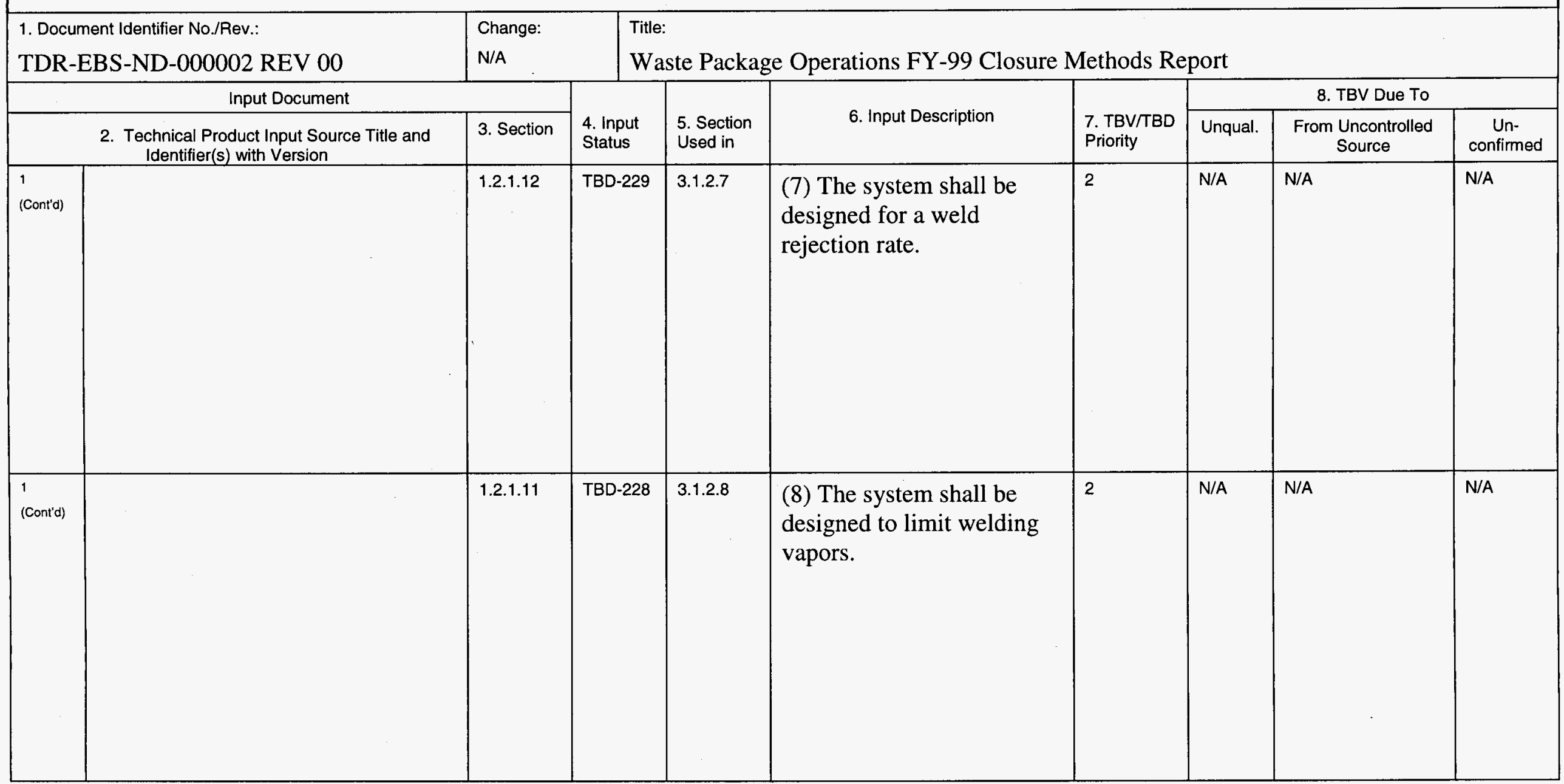




\section{OFFICE OF CIVILIAN RADIOACTIVE WASTE MANAGEMENT}

DOCUMENT INPUT REFERENCE SHEET

\begin{tabular}{|c|c|c|c|c|c|c|c|c|c|}
\hline \multicolumn{2}{|c|}{$\begin{array}{l}\text { 1. Document Identifier No./Rev.: } \\
\text { TDR-EBS-ND-000002 REV } 00\end{array}$} & $\begin{array}{l}\text { Change: } \\
\text { N/A }\end{array}$ & \multicolumn{7}{|c|}{$\begin{array}{l}\text { Title: } \\
\text { Waste Package Operations FY-99 Closure Methods Report }\end{array}$} \\
\hline \multicolumn{3}{|c|}{ Input Document } & \multirow[b]{2}{*}{$\begin{array}{l}\text { 4. Input } \\
\text { Status }\end{array}$} & \multirow[b]{2}{*}{$\begin{array}{l}\text { 5. Section } \\
\text { Used in }\end{array}$} & \multirow{2}{*}{ 6. Input Description } & \multirow[b]{2}{*}{$\begin{array}{l}\text { 7. TBV/TBD } \\
\text { Priority }\end{array}$} & \multicolumn{3}{|c|}{ 8. TBV Due To } \\
\hline & $\begin{array}{l}\text { 2. Technical Product Input Source Title and } \\
\text { Identifier(s) with Version }\end{array}$ & 3. Section & & & & & Unqual. & $\begin{array}{l}\text { From Uncontrolled } \\
\text { Source }\end{array}$ & $\begin{array}{c}\text { Un- } \\
\text { confirmed }\end{array}$ \\
\hline $\begin{array}{l}1 \\
\text { (Cont'd) }\end{array}$ & & 1.2.1.21 & TBD-228 & 3.1 .2 .9 & $\begin{array}{l}\text { (9) The system shall be } \\
\text { designed to limit welding } \\
\text { material deposition on the } \\
\text { outer surface of the } \\
\text { disposal container. }\end{array}$ & 2 & $N / A$ & N/A & $N / A$ \\
\hline 2 & $\begin{array}{l}\text { CRWMS M\&O 1999a. } \\
\text { Uncanistered Spent Nuclear Fuel } \\
\text { Disposal Container System } \\
\text { Description Document. } \\
\text { BBA000000-01717-1705-00004 } \\
\text { REV 01. Las Vegas, Nevada: } \\
\text { CRWMS M\&O. } \\
\text { ACC: MOL.19990608.0160. }\end{array}$ & 1.2 .1 .3 & $\mathrm{~N} / \mathrm{A}$ & 3.1 .1 .1 & $\begin{array}{l}\text { (1) No more than one } \\
\text { percent of all waste } \\
\text { packages breach during the } \\
\text { first } 1,000 \text { years after } \\
\text { emplacement. }\end{array}$ & N/A & N/A & N./A & $\mathrm{N} / \mathrm{A}$ \\
\hline
\end{tabular}




\section{OFFICE OF CIVILIAN RADIOACTIVE WASTE MANAGEMENT}

DOCUMENT INPUT REFERENCE SHEET

\begin{tabular}{|c|c|c|c|c|c|c|c|c|c|}
\hline \multicolumn{2}{|c|}{$\begin{array}{l}\text { 1. Document Identifier No./Rev.: } \\
\text { TDR-EBS-ND-000002 REV } 00\end{array}$} & $\begin{array}{l}\text { Change: } \\
\text { N/A }\end{array}$ & \multicolumn{7}{|c|}{$\begin{array}{l}\text { Title: } \\
\text { Waste Package Operations FY-99 Closure Methods Report }\end{array}$} \\
\hline \multicolumn{3}{|c|}{ Input Document } & \multirow[b]{2}{*}{$\begin{array}{l}\text { 4. Input } \\
\text { Status }\end{array}$} & \multirow[b]{2}{*}{$\begin{array}{l}\text { 5. Section } \\
\text { Used in }\end{array}$} & \multirow{2}{*}{ 6. Input Description } & \multirow[b]{2}{*}{$\begin{array}{l}\text { 7. TBV/TBD } \\
\text { Priority }\end{array}$} & \multicolumn{3}{|c|}{ 8. TBV Due To } \\
\hline & $\begin{array}{l}\text { 2. Technical Product Input Source Title and } \\
\text { Identifier(s) with Version }\end{array}$ & 3. Section & & & & & Unqual. & $\begin{array}{l}\text { From Uncontrolled } \\
\text { Source }\end{array}$ & $\begin{array}{c}\text { Un- } \\
\text { confirmed }\end{array}$ \\
\hline $\begin{array}{l}2 \\
\text { (Cont'd) }\end{array}$ & & 1.2.1.4 & N/A & 3.1.1.2 & $\begin{array}{l}\text { (2) Release rate of any } \\
\text { radionuclide from all } \\
\text { disposal containers. }\end{array}$ & N/A & $N / A$ & $N / A$ & N/A \\
\hline 3 & $\begin{array}{l}\text { CRWMS M\&O 1999b. } \\
\text { Classification of the Preliminary } \\
\text { MGDS Repository Design. } \\
\text { B00000000-01717-0200-00134 } \\
\text { REV 01. Las Vegas, Nevada: } \\
\text { CRWMS M\&O. } \\
\text { ACC: MOL.19981103.0546. }\end{array}$ & $\begin{array}{l}\text { Entire } \\
\text { document }\end{array}$ & $\mathrm{N} / \mathrm{A}$ & 3.2 & $\begin{array}{l}\text { (1) The disposal container } \\
\text { systems as MGR items } \\
\text { important to radiological } \\
\text { safety and waste isolation. }\end{array}$ & N/A & N/A & N/A & $N / A$ \\
\hline
\end{tabular}


OFFICE OF CIVILIAN RADIOACTIVE WASTE MANAGEMENT

DOCUMENT INPUT REFERENCE SHEET

\begin{tabular}{|c|c|c|c|c|c|c|c|c|c|}
\hline \multicolumn{2}{|c|}{$\begin{array}{l}\text { 1. Document Identifier No./Rev.: } \\
\text { TDR-EBS-ND-000002 REV } 00\end{array}$} & $\begin{array}{l}\text { Change: } \\
\text { N/A }\end{array}$ & \multicolumn{7}{|c|}{$\begin{array}{l}\text { Title: } \\
\text { Waste Package Operations FY-99 Closure Methods Report }\end{array}$} \\
\hline \multicolumn{3}{|c|}{ Input Document } & \multirow[b]{2}{*}{$\begin{array}{l}\text { 4. Input } \\
\text { Status }\end{array}$} & \multirow[b]{2}{*}{$\begin{array}{l}\text { 5. Section } \\
\text { Used in }\end{array}$} & \multirow{2}{*}{ 6. Input Description } & \multirow[b]{2}{*}{$\begin{array}{l}\text { 7. TBV/TBD } \\
\text { Priority }\end{array}$} & \multicolumn{3}{|c|}{ 8. TBV Due To } \\
\hline & $\begin{array}{l}\text { 2. Technical Product Input Source Title and } \\
\text { Identifier(s) with Version }\end{array}$ & 3. Section & & & & & Unqual. & $\begin{array}{c}\text { From Uncontrolled } \\
\text { Source } \\
\end{array}$ & $\begin{array}{c}\text { Un- } \\
\text { confirmed }\end{array}$ \\
\hline 4 & $\begin{array}{l}\text { CRWMS M\&O 1999c. QAP-2-0 } \\
\text { Activity Evaluation for WP } \\
\text { Engineering and Fabrication - SR, } \\
11012372 \text { M1 } \\
\text { Las Vegas , Nevada: CRWMS } \\
\text { M\&O. } \\
\text { ACC: MOL.19990330.0490. }\end{array}$ & $\begin{array}{l}\text { Entire } \\
\text { document }\end{array}$ & N/A & 3.2 & $\begin{array}{l}\text { (1) Determination if } \\
\text { workscope is subject } \\
\text { QARD requirements. }\end{array}$ & $N / A$ & N/A & N/A & N/A \\
\hline 5 & $\begin{array}{l}\text { CRWMS M\&O 1999d. Waste } \\
\text { Package Operations FY-99 } \\
\text { Closure Weld Development } \\
\text { Technical Guidelines Document. } \\
\text { BBA000000-01717-2500-00017 } \\
\text { REV 00. Las Vegas, Nevada: } \\
\text { CRWMS M\&O. } \\
\text { ACC: MOL.19990511.0239. }\end{array}$ & $\begin{array}{l}\text { Entire } \\
\text { document }\end{array}$ & N/A & 4.0 & $\begin{array}{l}\text { (1) Input is guidance for } \\
\text { the FY- } 99 \text { development } \\
\text { program. }\end{array}$ & N/A & N/A & N/A & N/A \\
\hline
\end{tabular}




\section{OFFICE OF CIVILIAN RADIOACTIVE WASTE MANAGEMENT}

DOCUMENT INPUT REFERENCE SHEET

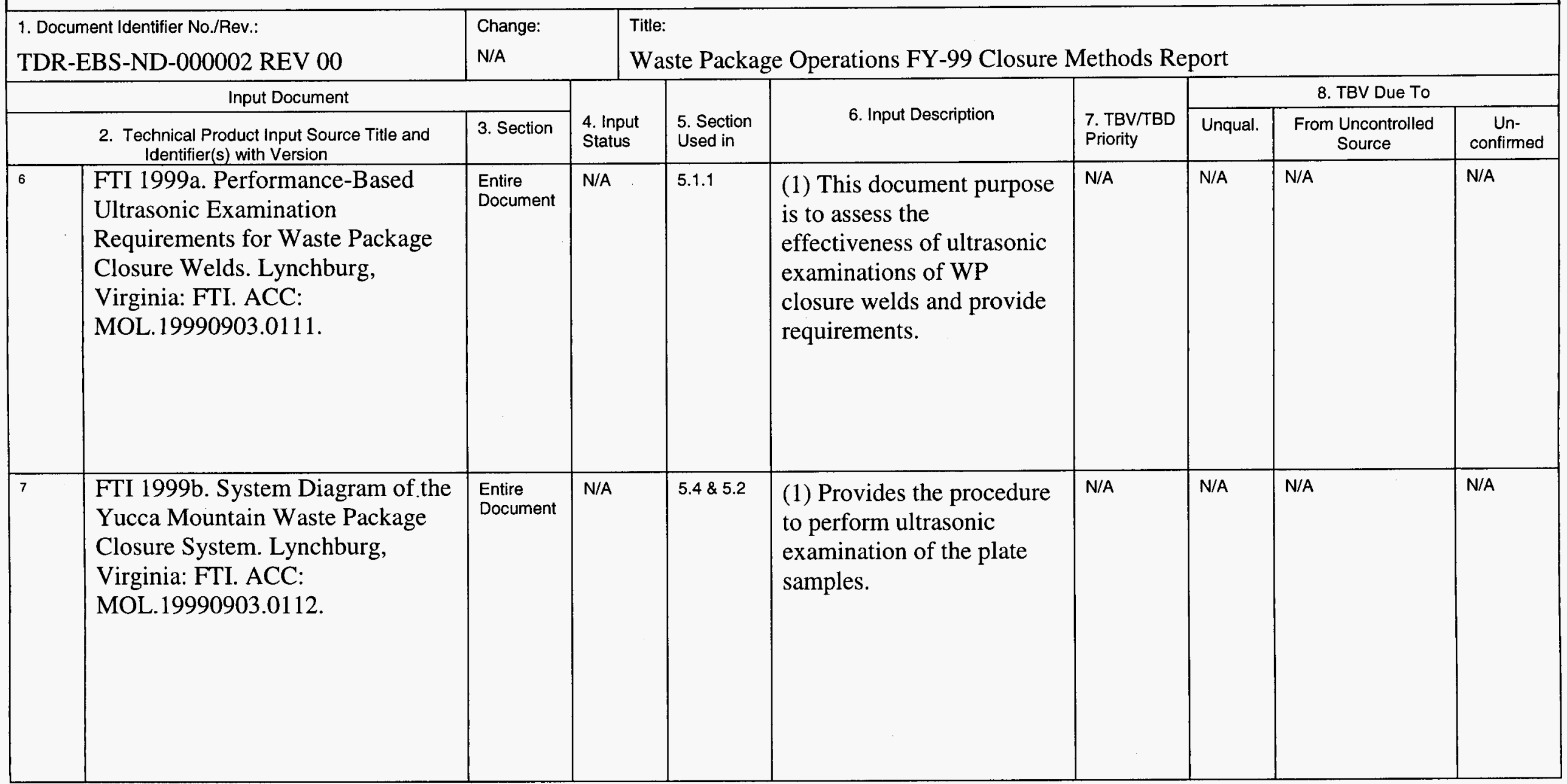




\section{OFFICE OF CIVILIAN RADIOACTIVE WASTE MANAGEMENT}

DOCUMENT INPUT REFERENCE SHEET

\begin{tabular}{|c|c|c|c|c|c|c|c|c|c|}
\hline \multicolumn{2}{|c|}{$\begin{array}{l}\text { 1. Document Identifier No./Rev.: } \\
\text { TDR-EBS-ND-000002 REV } 00\end{array}$} & $\begin{array}{l}\text { Change: } \\
\text { N/A }\end{array}$ & \multicolumn{7}{|c|}{$\begin{array}{l}\text { Title: } \\
\text { Waste Package Operations FY-99 Closure Methods Report }\end{array}$} \\
\hline \multicolumn{3}{|c|}{ Input Document } & \multirow[b]{2}{*}{$\begin{array}{l}\text { 4. Input } \\
\text { Status }\end{array}$} & \multirow[b]{2}{*}{$\begin{array}{l}\text { 5. Section } \\
\text { Used in }\end{array}$} & \multirow{2}{*}{ 6. Input Description } & \multirow[b]{2}{*}{$\begin{array}{l}\text { 7. TBV/TBD } \\
\text { Priority }\end{array}$} & \multicolumn{3}{|c|}{ 8. TBV Due To } \\
\hline & $\begin{array}{l}\text { 2. Technical Product Input Source Title and } \\
\text { Identifier(s) with Version }\end{array}$ & 3. Section & & & & & Unqual. & $\begin{array}{l}\text { From Uncontrolled } \\
\text { Source } \\
\end{array}$ & $\begin{array}{c}\text { Un- } \\
\text { confirmed }\end{array}$ \\
\hline 8 & $\begin{array}{l}\text { Office of Civilian Radioactive } \\
\text { Waste Management (OCRWM) } \\
\text { 1998. Quality Assurance } \\
\text { Requirements and Description. } \\
\text { DOE/RW-0333P REV 08. } \\
\text { Washington D.C.: U.S. } \\
\text { Department of Energy (DOE). } \\
\text { ACC: MOL.19980601.0002. }\end{array}$ & $\begin{array}{l}\text { Entire } \\
\text { Document }\end{array}$ & $\mathrm{N} / \mathrm{A}$ & 3.2 & $\begin{array}{l}\text { (1) This is provided as a } \\
\text { reference only to indicate } \\
\text { that the report is subject to } \\
\text { its controls. }\end{array}$ & N/A & $\mathrm{N} / \mathrm{A}$ & $N / A$ & N/A \\
\hline 9 & $\begin{array}{l}\text { OCRWM 1999a. Monitored } \\
\text { Geologic Repository Requirements } \\
\text { Document. YMP/CM-0025 REV } \\
\text { 03. DCN01. Las Vegas, Nevada: } \\
\text { DOE. } \\
\text { ACC: MOL.19980520.1022. }\end{array}$ & 3 & N/A & 3.1 & $\begin{array}{l}\text { (1) Waste } \\
\text { package/disposal container } \\
\text { project level requirements. }\end{array}$ & N/A & $N / A$ & N/A & $\mathrm{N} / \mathrm{A}$ \\
\hline
\end{tabular}




\section{OFFICE OF CIVILIAN RADIOACTIVE WASTE MANAGEMENT}

DOCUMENT INPUT REFERENCE SHEET

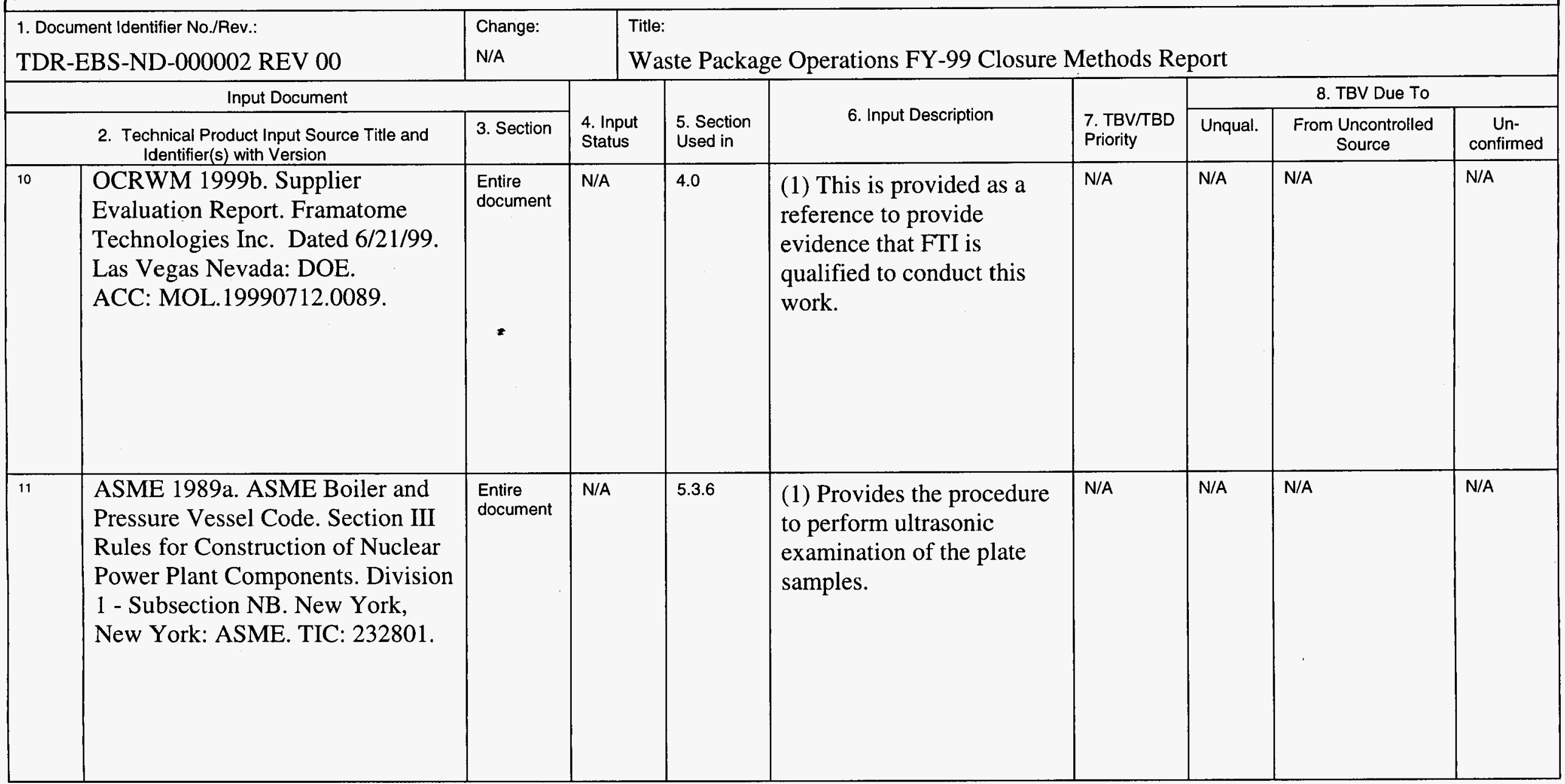


OFFICE OF CIVILIAN RADIOACTIVE WASTE MANAGEMENT

DOCUMENT INPUT REFERENCE SHEET

\begin{tabular}{|c|c|c|c|c|c|c|c|c|c|}
\hline \multicolumn{2}{|c|}{$\begin{array}{l}\text { 1. Document Identifier No./Rev.: } \\
\text { TDR-EBS-ND-000002 REV } 00\end{array}$} & $\begin{array}{l}\text { Change: } \\
\text { N/A }\end{array}$ & \multicolumn{7}{|c|}{$\begin{array}{l}\text { Title: } \\
\text { Waste Package Operations FY-99 Closure Methods Report }\end{array}$} \\
\hline \multicolumn{3}{|c|}{ Input Document } & \multirow[b]{2}{*}{$\begin{array}{l}\text { 4. Input } \\
\text { Status }\end{array}$} & \multirow[b]{2}{*}{$\begin{array}{l}\text { 5. Section } \\
\text { Used in }\end{array}$} & \multirow{2}{*}{ 6. Input Description } & \multirow[b]{2}{*}{$\begin{array}{l}\text { 7. TBV/TBD } \\
\text { Priority }\end{array}$} & \multicolumn{3}{|c|}{ 8. TBV Due To } \\
\hline & $\begin{array}{l}\text { 2. Technical Product Input Source Title and } \\
\text { Identifier(s) with Version }\end{array}$ & 3. Section & & & & & Unqual. & $\begin{array}{c}\text { From Uncontrolled } \\
\text { Source }\end{array}$ & $\begin{array}{c}\text { Un- } \\
\text { confirmed }\end{array}$ \\
\hline 12 & $\begin{array}{l}\text { ASME 1989b. ASME Boiler and } \\
\text { Pressure Vessel Code. Section V } \\
\text { Nondestructive Examination. New } \\
\text { York, New York: ASME. TIC: } \\
245342 \text {. }\end{array}$ & $\begin{array}{l}\text { Entire } \\
\text { document }\end{array}$ & $\mathrm{N} / \mathrm{A}$ & 5.3 .6 & $\begin{array}{l}\text { (1) Provides the procedure } \\
\text { to perform ultrasonic } \\
\text { examination of the plate } \\
\text { samples. }\end{array}$ & N/A & $N / A$ & N/A & $N / A$ \\
\hline
\end{tabular}

